\author{
Joanna M. MOCZYDŁOWSKA ${ }^{1}$ \\ Karol KOWALEWSKI ${ }^{2}$
}

\title{
STEREOTYP PRACOWNIKA W WIEKU 50+ JAKO POTENCJALNE ŹRÓDŁO ZACHOWAŃ DYSKRYMINACYJNYCH W ŚRODOWISKU PRACY
}

\begin{abstract}
Celem artykułu jest systematyzacja wiedzy na temat stereotypu pracownika dojrzałego i w podeszłym wieku. Artykuł zawiera przegląd interdyscyplinarnych badań naukowych nad cechami oraz zachowaniami w środowisku pracy przypisywanymi osobom $\mathrm{z}$ tej grupy wiekowej. Wybór tematu wynika z przekonania, że tylko dogłębne poznanie stereotypu pracownika 50+ pozwoli na takie ukierunkowanie procesu zarządzania, by był on wolny od zachowań dyskryminacyjnych i działań marginalizujących starszych wiekiem pracowników.

W artykule omówiono takie pojęcia jak: stereotyp, ageizm, dyskryminacja i marginalizacja. Ukazano cechy oraz zachowania, które są przypisywane osobom z grupy wiekowej $50+$, oraz przejawy zachowań dyskryminacyjnych przedstawione w wybranych raportach z ogólnopolskich badań prowadzonych na ten temat wśród pracowników i pracodawców. $\mathrm{W}$ ostatniej części dokonano syntezy wniosków z badań poświęconych zagadnieniu dyskryminacji pracowników w dojrzałym i podeszłym wieku. Opinie osób w wieku 50+ skonfrontowano z uwagami pracodawców oraz młodszych pracowników.

Zebrany materiał empiryczny pozwolił na sformułowanie wniosku, że zagadnienie marginalizacji osób starszych w środowisku pracy jest w Polsce raczej bagatelizowane, a natura i siła oddziaływania stereotypu pracownika dojrzałego mało uświadamiane. Do nierównego traktowania pracowników ze względu na wiek nie przyznają się pracodawcy oraz młodsi pracownicy, chociaż fakty i opinie osób będących adresatem działań dyskryminacyjnych wskazują na inny stan rzeczy. Osoby w wieku 50+ zauważają, że są pomijane przy podwyżkach i premiach, ogranicza się im możliwości rozwoju, ignoruje ich potrzeby. Jako ważne źródło tych zachowań autorzy uznają stereotypowe postrzeganie pracowników 50+.

Słowa kluczowe: stereotyp, wiek, wiekizm, marginalizacja, dyskryminacja
\end{abstract}

\section{WPROWADZENIE}

Nowelizacja ustawy o emeryturach i rentach z listopada 2012 r., na mocy której wiek emerytalny będzie stopniowo podwyższany do 67. roku życia dla obu płci, wywołała wiele trwających do dziś dyskusji. Do najczęściej podejmowanych tematów należy problem efektywności zawodowej starszych wiekiem pracowników. Zarówno w debacie publicystycznej, jak i naukowej pojawia się wątpliwość, czy pracownik z grupy 50+ (55+, $60+)$ jest pełnowartościowy z punktu widzenia oczekiwań pracodawcy. Trudno dyskutować $\mathrm{z}$ tym, że wraz $\mathrm{z}$ wiekiem następują naturalne procesy obniżające sprawność psychofizyczną człowieka, jednak w ocenie autorów dominującym źródłem lęku pracodawców

\footnotetext{
${ }^{1}$ Dr hab. Joanna M. Moczydłowska, prof. Politechniki Białostockiej, Wydział Zarządzania, ul. Ojca Tarasiuka 2, 16-001 Kleosin, e-mail: joanna@ moczydlowska.pl (autor korespondencyjny)

${ }^{2}$ Dr Karol Kowalewski, Wyższa Szkoła Finansów i Zarządzania w Białymstoku, Filia w Ełku, Wydział Zarządzania, ul. Grunwaldzka 1, 19-300 Ełk, e-mail: karol.kowalewski@ wsfiz.edu.pl
} 
i menedżerów przed wydłużaniem się czasu aktywności zawodowej ich podwładnych jest stereotypowe postrzeganie pracowników w podeszłym wieku.

Autorzy mają świadomość, że pojęcie ,,pracownik dojrzały” jest bardzo nieprecyzyjne, zwłaszcza że w bogatej literaturze poświęconej problematyce wieku i zarządzania wiekiem proponuje się bardzo różne wartości w klasyfikacji wieku pracowników czy etapów kariery. Na potrzeby tej publikacji przyjęto, że będzie to wiek powyżej 50 lat. Warto zauważyć, że chociaż rozważania na temat dyskryminacji i marginalizacji mają w naukach społecznych i humanistycznych długą i bogatą historię, to badania dotyczące ekonomicznych aspektów tych problemów są znacząco mniej popularne. Brakuje w Polsce systematycznie prowadzonych prac naukowych na ten temat, a powszechnie dostępne analizy i raporty mają zazwyczaj charakter przyczynkowy i fragmentaryczny, co istotnie utrudnia rzetelne zobrazowanie skali tych zjawisk. Ogólnopolskie badania obejmujące problem dyskryminacji, a tym bardziej nierównego traktowania pracowników ze względu na wiek, należą w Polsce do rzadkości. Sytuacji nie ułatwia również fakt, że analizowane zjawisko należy do tematów drażliwych i trudnych do mierzenia w sondażach.

Celem artykułu jest systematyzacja wiedzy na temat stereotypu starszego wiekiem pracownika. Artykuł zawiera przegląd interdyscyplinarnych badań naukowych nad cechami oraz zachowaniami w środowisku pracy przypisywanym osobom z tej grupy wiekowej oraz przejawami zachowań dyskryminacyjnych mogących mieć źródło w stereotypowym postrzeganiu przydatności zawodowej osób powyżej 50 lat. Wybór tematu wynika $\mathrm{z}$ przekonania, że tylko dogłębne poznanie stereotypu pracownika 50+ pozwoli na takie ukierunkowanie procesu zarządzania, by był on wolny od działań dyskryminacyjnych i marginalizujących pracowników w podeszłym wieku.

\section{STEREOTYP PRACOWNIKA 50+}

Stereotyp jest wynikiem generalizacji, w której ramach identyczne charakterystyki zostają przypisane wszystkim członkom danej grupy, niezależnie od istniejących między nimi różnic. Stereotypy powstają w wyniku klasyfikowania obiektów lub ludzi jako członków pewnej grupy lub kategorii. Jeden z pionierów badań nad stereotypami, Gordon Allport, określił je mianem ,prawa mniejszego wysiłku”3. Twierdził on, że świat jest zbyt złożony i zbyt skomplikowany, by człowiek mógł wyrobić sobie szczegółową opinię o wszystkim, co go otacza. Dlatego ludzie, mając ograniczoną zdolność do przetwarzania informacji, stosują swoiste skróty poznawcze, czyli praktyczne, uogólnione reguły poznania. Tak rozumiana stereotypizacja jest procesem naturalnym i dlatego nie może być sama w sobie traktowana jako zjawisko patologiczne. Ludzie często posługują się stereotypami o charakterze heurystyk czy też dróg na skróty. Stereotypy dają poczucie poznawczej kontroli sytuacji społecznej, pozwalają lepiej orientować się w otaczającej rzeczywistości, podejmować szybsze decyzje. Ułatwiają też komunikację międzyludzką, służą do zapewnienia poczucia bezpieczeństwa i kreowania określonych zachowań ${ }^{4}$. Niestety, cechą stereotypów jest to, że zawierają bardzo ogólny, uproszczony i zabarwiony emocjonalnie, a przez to nieprawdziwy obraz ludzi i zjawisk, których dotyczą. To powoduje, że ich

\footnotetext{
${ }^{3}$ Cyt. za: E. Aronson, T.D. Wilson, R.M. Akert, Psychologia społeczna. Serce i umyst, Zysk i S-ka, Poznań 1997, s. 543.

${ }^{4}$ Z. Chlewiński, Stereotypy: struktura, funkcje, geneza, [w:] Stereotypy i uprzedzenia, red. Z. Chlewiński, I. Kurcz, Instytut Psychologii PAN, Warszawa 1992.
} 
przydatność w poznawaniu świata jest tylko pozorna, zwłaszcza że cechują je znaczny brak elastyczności i odporność na zmianę, a to oznacza, że nawet jeśli człowiek otrzymuje informacje przeczące prawdziwości stereotypu, odrzuca je bądź bagatelizuje. Dlatego stereotypowy obraz starszych wiekiem pracowników jest tak groźny. Nie jest to bowiem prawdziwa charakterystyka tej grupy osób, lecz zbiór wartościujących przekonań, sądów, opinii stygmatyzujących ich jako mniej kompetentnych, a przez to mniej wartościowych z punktu widzenia pracodawców.

Stereotyp pracownika z grupy 50+ bazuje na prawdziwym stwierdzeniu, że z wiekiem u każdego człowieka następują naturalne zmiany fizyczne i psychiczne związane z procesem starzenia się. Powodują one, że wraz z wiekiem może spadać wydajność pracownika, zwłaszcza w zakresie pracy umysłowej wymagającej percepcji sensorycznej, pamięci operacyjnej i szybkiego przetwarzania informacji ${ }^{5}$. Jednak wnioski zbudowane na tej podstawie nie uwzględniają zróżnicowanego tempa starzenia się i znaczących różnic indywidualnych występujących między ludźmi w każdej, a więc także w tej grupie wiekowej. Do najważniejszych zmian eksponowanych u pracownika w podeszłym wieku należą: większa męczliwość, nasilający się lęk przed zmianami, niechęć do uczenia się, konserwatyzm, tzw. „starcza nieomylność”, czyli przekonanie ludzi starszych, że wszystko wiedzą i robią najlepiej, bo mają większe doświadczenie. Wymienione cechy są fundamentem stereotypu wyłaniającego się z badań przeprowadzonych wśród pracodawców. W świadomości pracodawców u pracownika 50+ dominują: niskim poziom wykształcenia i umiejętności technicznych, niska wydajność pracy, niesatysfakcjonująca kreatywność i brak innowacyjności czy wreszcie słabe zdolności przystosowawcze do zmieniających się wymagań rynku ${ }^{6}$. W badaniach Richarda A. Posthuma i Michael A. Campion ${ }^{7}$ ten nieprzychylny wizerunek dodatkowo wzmacniają takie cechy, jak: niższy poziom aspiracji oraz mniejsza niż u młodszych pracowników odporność na oddziaływanie czynników stresujących.

Jednym z elementów silnie eksponowanych w obrazie kompetencji pracowników z grupy 50+ jest poziom ich akcepcji dla nowych technologii i ściśle z nim powiązany poziom ich umiejętności technicznych. Badania na ten temat są niejednoznaczne. Starsze ${ }^{8}$ wskazują na to, że w postawach pracowników 50+ wobec nowych technologii dominują niechęć i silny lęk. Pokolenie 50+ bywa wręcz określane mianem „wykluczonego cyfrowo", przy czym nie chodzi tu o utrudniony dostęp do komputera czy internetu, ale o brak motywacji do korzystania $z$ tych narzędzi i umiejętności posługiwania się nimi ${ }^{9}$. Nowsze badania $^{10}$ pozwalają na sformułowanie innego wniosku, że rośnie gotowość starszych pracowników do rozwijania swoich umiejętności IT i świadomość, że jest to ważny element ich kompetencji zawodowych.

\footnotetext{
${ }^{5}$ Por. W. Piesiak, Genetyka starzenia się mózgu, „Neurokognitywistyka w Patologii i Zdrowiu. Roczniki Pomorskiej Akademii Medycznej w Szczecinie 2011-2013”, Szczecin 2013, s. 56-66.

${ }^{6}$ A. Richert-Kaźmierska, K. Stankiewicz, Kompetencje pracowników 55+ w opinii pracowników z młodszych grup wiekowych, „E-mentor”, 48/1 (2013).

${ }^{7}$ R.A. Posthum, M.A. Campion, Age stereotypes in the workplace: common stereotypes, moderators and future research directions, „Journal of Management” 2009/35, s. 158-188.

${ }^{8} \mathrm{P}$. Turner, S. Turner, G. Van de Walle, How older people account for their experiences with interactive technology, „Behavior and Information Technology” 2007/26, s. 287-296.

9 J.A.G.M. Van Dijk, The Deepening Divide, Inequality in the information Society, Sage, London 2005.

${ }^{10}$ T.E. Rizutto, Age and technology innovation in the workplace: Does work context matter?, „Computers in Human Behavior" 2011/27, s. 1612-1620.
} 
W polskich warunkach w obrazie pracownika z grupy wiekowej 50+ eksponuje się atrybuty charakterystyczne dla homo sovieticus: roszczeniowego, niesamodzielnego spadkobiercę najgorszych cech systemu socjalistycznego nieprzystosowanego do pracy w warunkach wolnego rynku ${ }^{11}$. Tak nieprzychylny wizerunek pracowników z grupy 50+ wpływa na ich samoocenę, a także na zachowania w środowisku pracy. Odbierając sygnały świadczące o negatywnej ocenie ich kompetencji, internalizują takie przekonania i zaczynają postępować zgodnie z nimi ${ }^{12}$. Starsi pracownicy często sami o sobie myślą, że są mało wydajnymi, gorszymi pracownikami i powinni ustąpić miejsca młodym ${ }^{13}$. Jak pokazują badania Bilans Kapitału Ludzkiego przeprowadzone przez Polską Agencję Rozwoju Przedsiębiorczości w 2011 r., wraz z wiekiem w mniejszym lub większym stopniu spada samoocena respondentów w zakresie wszystkich kompetencji ${ }^{14}$.

Mimo że w opinii społecznej wydaje się dominować negatywny stereotyp starszych pracowników czy ludzi w podeszłym wieku w ogóle, trzeba odnotować również przykłady pozytywnych cech i zachowań, które są zauważane przez pracodawców. Z badań Łucji Krzyżanowskiej ${ }^{15}$ wynika, że są to głównie: doświadczenie zawodowe wynikające z długoletniej praktyki, doświadczenie życiowe, dyspozycyjność związana z tym, że ich życie rodzinne jest bardziej ustabilizowane (najczęściej mają już odchowane dzieci, więc mogą więcej czasu poświecić pracy zawodowej), lojalność wobec pracodawcy, większy szacunek wobec pracy i traktowanie jej jako wartości samej w sobie, przywiązanie emocjonalne do miejsca pracy, w którym niekiedy przepracowali większość swojego życia, większa solidność, staranność, odpowiedzialność i stabilność emocjonalna.

\section{ZACHOWANIA DYSKRYMINACYJNE I MARGINALIZUJĄCE STARSZYCH WIEKIEM PRACOWNIKÓW - PRZEGLĄD WYNIKÓW BADAŃ}

W badaniu Głównego Urzędu Statystycznego dotyczącego jakości życia i spójności społecznej w Polsce, które przeprowadzono w 2011 r., ujawniono, że osób w podeszłym wieku bynajmniej nie uznaje się za grupę dyskryminowaną. Wśród dwunastu grup społecznych uwzględnionych w ogólnopolskiej ankiecie, za najbardziej dyskryminowaną populację uważa się bezdomnych (blisko 67\% wskazań), następnie - osoby o odmiennej orientacji seksualnej (59\%), a na trzecim miejscu - osoby niepełnosprawne dotknięte kalectwem (45\%). Grono starszych osób zostało sklasyfikowane dopiero na dziewiątym miejscu w tym rankingu (27\%). Również badania prowadzone przez ALK i SMG/KRC wydają się nie potwierdzać opinii o dyskryminacji osób w podeszłym wieku w miejscu pracy. Zdaniem $75 \%$ badanych pracowników z województwa mazowieckiego postawa pracodawców wobec tej grupy zatrudnionych jest „,raczej życzliwa” lub „,bardzo życzliwa". Przeciwnego zdania jest jedynie $12 \%$ respondentów. Jeszcze bardziej jednoznaczne są samooceny pracodawców, aż $89 \%$ z nich stwierdza, że ich stosunek względem starszych pracowników jest pozytywny. Taka sama liczebnie grupa pracodawców uważa, że

\footnotetext{
${ }^{11}$ Ł. Krzyżanowska, Homo sovieticus czy doświadczony pracownik? - opinie pracodawców o pracownikach w wieku 50+, ,Acta Universitatis Lodziensis. Folia Oeconomica” 2013/291, s. 85.

${ }^{12}$ L.T. O’Brien, M.L. Hummert, Memory performance of late middle-age adults: Contrasting self-stereotyping and stereotype threat accounts of assimilation to age stereotypes, ,Social Cognition” 2006/24, s. 338-358.

13 Ilekroć w artykule pojawia się określenie „młody pracownik” lub „młodszy pracownik” należy przez to rozumieć osoby do 35. roku życia.

${ }^{14}$ Cyt. za: W. Sokołowski, Osoby 45/50+ zmagają się z dyskryminacją, kariera epr.pl (dostęp: 13.01.2015).

${ }^{15}$ Ł. Krzyżanowska, op. cit., s. 82-86.
} 
są oni traktowani jednakowo (83\%), a nawet lepiej (6\%) niż pracownicy młodsi ${ }^{16}$. Wśród pracodawców z województwa dolnośląskiego dominuje zaś przekonanie, że pracownicy starsi nie muszą być mniej wydajni niż ich młodsi współpracownicy, co potwierdza w swoich opiniach $70 \%$ badanych przedsiębiorców. Odmiennego zdania jest 17\% ankietowanych. Gdyby zaś zaszła konieczność redukcji etatów, $74 \%$ z nich twierdzi, że nie brałoby pod uwagę kryterium wieku, a 9\% skłaniałoby się nawet do zwolnienia młodszych pracowników. Jedynie $4 \%$ badanych pracodawców wolałoby zwolnić osoby starsze $^{17}$.

Rys. 1. Obawy wobec pracowników w podeszłym wieku w opinii pracodawców, którzy zatrudniali już takie osoby

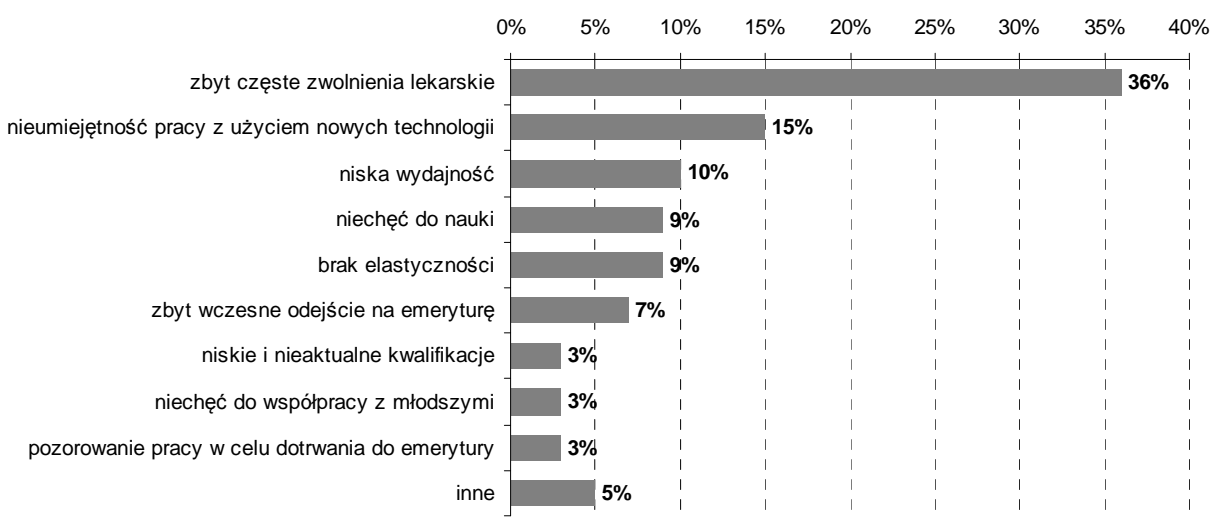

Źródło: opracowanie własne na podstawie: Sytuacja osób powyżej 50. i 60. roku życia na rynku pracy Dolnego Śląska, red. J. Sawicki, Centrum Monitoringu Społecznego i Kultury Obywatelskiej, Wrocław 2013, s. 102.

Z przedstawionych wyników badań może zatem wynikać spostrzeżenie, że problem dyskryminacji, jeżeli w ogóle istnieje, występuje rzadko i nie jest poważny. Należy jednak zwrócić uwagę, że przytoczone wyniki to przede wszystkim: opinie, sądy i inne określenia wolicjonalne przedsiębiorców i/lub młodszych pracowników. W rzeczywistości nie jesteśmy jednak odbiorcami zamiarów i zapowiedzi, ale konkretnych działań i decyzji, które w wielu wypadkach okazują się odmienne od stanowisk prezentowanych w badaniach ankietowych. Potwierdzają to fakty oraz relacje osób bezpośrednio zainteresowanych, które przedstawiono w dalszej części artykułu.

Odnosząc się ponownie do badania przeprowadzonego wśród ponad 600 pracodawców z województwa dolnośląskiego, warto zaznaczyć, że co trzeci badany, który zatrudniał lub zatrudnia obecnie pracownika w podeszłym wieku, nie ma żadnych obaw w stosunku do ponownego zatrudniania takich osób. Pracodawcy, którzy dotychczas nie zatrudniali starszych pracowników, są nieco bardziej powściągliwi w formułowaniu takich

\footnotetext{
16 M. Skrzek-Lubasińska, Spoteczne uwarunkowania aktywizacji zawodowej osób starszych 50+, [w:] Kompleksowy program aktywizacji osób starszych 50+, red. Cz. Szmidt, Akademia Leona Koźmińskiego, Warszawa 2012, s. 332-333.

${ }^{17}$ Sytuacja osób powyżej 50. i 60. roku życia na rynku pracy Dolnego Ślaska, red. J. Sawicki, Centrum Monitoringu Społecznego i Kultury Obywatelskiej, Wrocław 2013, s. 103-104.
} 
odpowiedzi $(27 \%)^{18}$. Należy jednak zadać pytanie: co sądzi pozostała część, czyli zdecydowana większość, badanych pracodawców?

Rys. 2. Obawy wobec starszych pracowników w opinii pracodawców, którzy nie zatrudniali takich osób

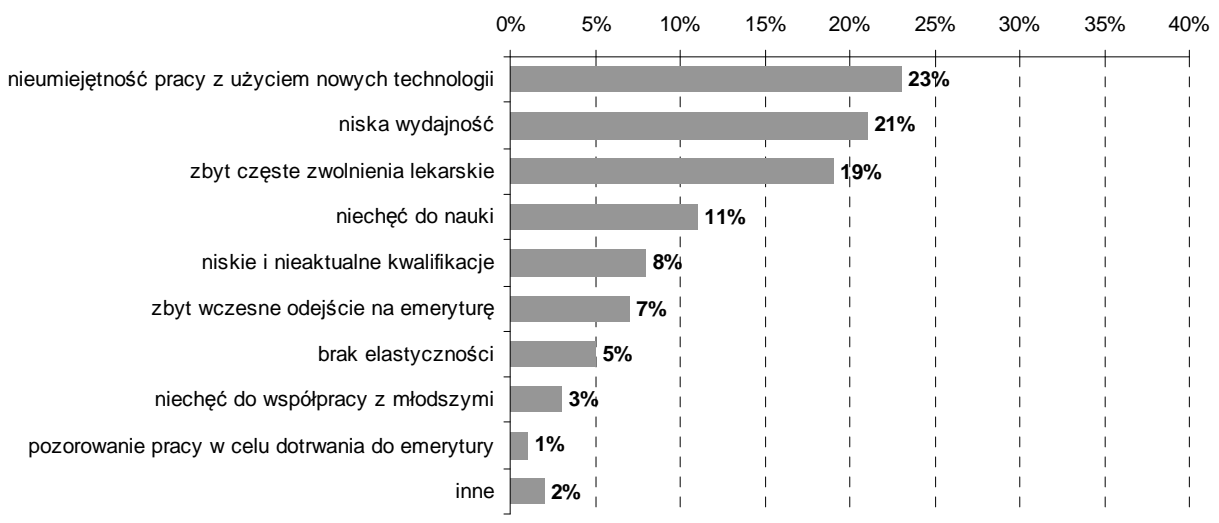

Źródło: opracowanie własne na podstawie: Sytuacja osób powyżej 50. i 60. roku życia na rynku pracy Dolnego Śląska, red. J. Sawicki, Centrum Monitoringu Społecznego i Kultury Obywatelskiej, Wrocław 2013, s. 102.

Z danych przedstawionych na rysunkach 1 i 2 wynika, że grupa pracodawców, która obawia się zatrudniania starszych pracowników, przedstawia stosunkowo dużo różnorodnych wątpliwości. Wśród formułowanych obiekcji dominują trzy uwagi dotyczące: chorowitości starszych pracowników, a co z tego wynika - zbyt częstej ich absencji w pracy; nieumiejętności pracy z użyciem nowych technologii oraz niskiej wydajności. Porównując struktury odpowiedzi przedstawione na rysunku 1 i rysunku 2, można też zauważyć, że pracodawcy, którzy doświadczyli pracy ze starszymi pracownikami mają najwięcej zastrzeżeń do częstych zwolnień lekarskich tych osób. Dostrzegalne jest także częstsze wyrażanie obaw przez pracodawców, którzy nie zatrudniali wcześniej starszych pracowników. Może to świadczyć o dość stereotypowym postrzeganiu przez nich tej grupy wiekowej. Co istotne, łącznie pracodawcy przedstawiali aż kilkanaście zróżnicowanych czynników stanowiących źródło obiekcji wobec zatrudniania pracowników starszych.

Wydaje się, że wiele przedstawianych obaw, jak również częstotliwość ich wskazywania stoją niejako w sprzeczności z odpowiedziami pracodawców na inne pytania (w tym samym badaniu), dotyczące oceny wydajności oraz bezstronnego podejścia do pracowników w różnym wieku, a nawet rzekomego faworyzowania seniorów.

Przechodząc do zagadnienia dyskryminacji starszych pracowników na rynku pracy, warto zauważyć, że za osoby dyskryminowane uważa się w Polsce blisko $10 \%$ ludności powyżej 16. roku życia ${ }^{19}$. Relatywnie najczęściej opinię taką formułują właśnie ludzie

\footnotetext{
${ }^{18}$ Ibidem, s. 102.

${ }^{19}$ Jakość życia w Polsce, GUS, Warszawa 2014, s. 18.
} 
w wieku 50-64 lat ${ }^{20}$. Należy dodać, że pod koniec 2013 r. osoby z grupy wiekowej 50+ stanowiły ponad $24 \%$ ogółu zarejestrowanych bezrobotnych w porównaniu z 22,8\% przed rokiem i niespełna 16\% w 2005 r. Oznacza to, że na przestrzeni ostatnich ośmiu lat udział ten zwiększył się o ponad $8 \%{ }^{21}$. Analizowany proces związany jest oczywiście ze starzeniem się społeczeństwa ${ }^{22}$, ale wydaje się, że sprowadzanie opisywanych zmian tylko do tej jednej przyczyny jest nadmiernym uproszczeniem zjawiska.

W opozycji do ukazanych opinii pracodawców pozostają wyniki badań na temat rekrutacji kandydatów do pracy. Monitoring ogłoszeń o pracę przeprowadzony przez Polskie Towarzystwo Prawa Antydyskryminacyjnego wykazał, że na blisko 61 tysięcy przeanalizowanych ogłoszeń w niemal 25 tysiącach przypadków stwierdzono nieprawidłowości, które mogą prowadzić do dyskryminacji w zatrudnieniu, z czego $10 \%$ dotyczyło wieku ${ }^{23}$. Więcej zarzutów co do bezstronności ogłoszeń odnosiło się jedynie do płci kandydatów. Podobne wnioski wynikają z badania przeprowadzonego przez Polskie Stowarzyszenie Edukacji Prawnej, podczas którego zbadano treść ponad 37 tysięcy ogłoszeń. W tym wypadku odsetek ogłoszeń, w których wystąpiła jakakolwiek z przesłanek dyskryminacyjnych, był wprawdzie wyraźnie mniejszy (niespełna 6\%), ale ponownie okazało się, że dyskryminacja ze względu na wiek jest drugą w kolejności pod względem liczby naruszeń (najczęściej dyskryminuje się kandydatów ze względu na płeć). Z badań wynika ponadto, że dyskryminacja wiekowa występuje także w $42 \%$ wszystkich innych badanych przejawów dyskryminacji, a grupą ją dotkniętą są zwłaszcza osoby starsze. Ogłoszenia, w których doszło do naruszenia zasady niedyskryminacji, były zamieszczane w przeważającej większości przez samych pracodawców. W pozostałych sytuacjach ogłoszeniodawcami były podmioty zajmujące się profesjonalnie poszukiwaniem pracowników oraz urzędy pracy $^{24}$.

Występowanie wielu nieprawidłowości w procesie rekrutacji pracowników na pewno nie pozostaje bez wpływu na samoocenę sytuacji starszych osób w społeczeństwie i na rynku pracy. Tezę tę potwierdza badanie sondażowe przeprowadzone wśród ponad 1200 osób 50+ w Białymstoku, Inowrocławiu, Kielcach, Kraśniku, Lublinie, Poznaniu, Tczewie i Warszawie ${ }^{25}$. W odczuciu połowy respondentów osoby w podeszłym wieku nie są traktowane z należytym szacunkiem. Jeszcze liczniejsze grono badanych (58\%) uważa, że dojrzali wiekiem kandydaci są traktowani gorzej niż inni właśnie z powodu wieku. Najwięcej respondentów (82\%) jako przyczynę nierównego, gorszego traktowania osób starszych wskazało brak kultury i właściwego wychowania osób młodszych. Na brak wiedzy o potrzebach i ograniczeniach starości zwróciła uwagę niemal połowa ankietowanych $(49 \%)^{26}$.

\footnotetext{
20 Jakość życia i spójność spoteczna 2011 (wstępna analiza wyników badania ankietowego), Notatka informacyjna, GUS, Warszawa 2011, s. 27.

${ }^{21}$ Osoby powyżej 50 roku życia na rynku pracy w 2013 roku, Ministerstwo Pracy i Polityki Społecznej, Warszawa 2014, s. 1.

22 Więcej na ten temat: J.M. Moczydłowska, K. Kowalewski, Nowe koncepcje zarządzania ludźmi, Difin, Warszawa 2014, s. 136-139.

${ }^{23}$ Równe traktowanie $w$ zatrudnieniu. Przepisy a rzeczywistość, red. K. Kędziora, K. Śmiszka, M. Zima, Polskie Towarzystwo Prawa Antydyskryminacyjnego, Warszawa 2009, s. 11-14.

${ }^{24}$ I. Jaroszewska-Ignatowska, op. cit., s. 29-30.

${ }^{25}$ Patrz: M. Łuczak, Dyskryminacja ze względu na wiek w oczach ludzi starszych. Prezentacja wyników badania przeprowadzonego przez forum 50+. Seniorzy XXI wieku!, [w:] Stop dyskryminacji..., s. 91-96.

${ }^{26}$ Ibidem, s. 95.
} 
Rys. 3. Przyczyny niezadowolenia z obecnej pracy w opinii starszych pracowników

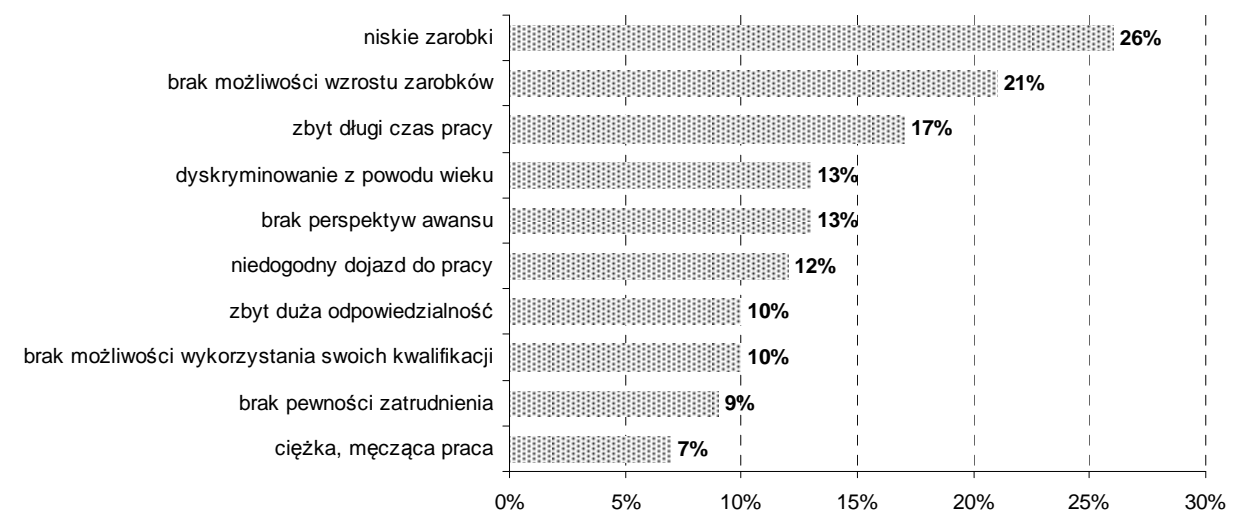

Źródło: opracowanie własne na podstawie: B. Radzka, Praca w hierarchii wartości pracowników 50+ $i$ wartości zwiąane z praca, [w:] Kompleksowy program aktywizacji osób starszych 50+, red. Cz. Szmidt, Akademia Leona Koźmińskiego, Warszawa 2012, s. 279.

W badaniu przeprowadzonym przez ALK i SMG/KRC zapytano pracowników 50+ o oczekiwania wobec idealnej pracy oraz ewentualne przyczyny niezadowolenia. Wyniki, które przedstawiono na rysunku 3, wskazują, że najważniejsze mankamenty obecnie wykonywanej pracy są związane z kwestiami finansowymi. Na problem otrzymywania niskiego wynagrodzenia wskazało $26 \%$ badanych, a na brak możliwości wzrostu zarobków - $21 \%$, co w wypadku realiów polskiej gospodarki trudno uznać za zaskakujące. Na czwartym miejscu pod względem ważności (13\%) wskazano dyskryminowanie ze względu na wiek ${ }^{27}$. W tym samym badaniu poproszono również pracodawców i kadrę zarządzającą o wskazanie ewentualnych różnic w traktowaniu pracowników młodszych i starszych. Wśród najczęściej wskazywanych dysproporcji dominowały uwagi o wynagradzaniu. Część pracowników była zdania, że osoby starsze są pomijane przy: podwyżkach, premiach i ogólnie mniej zarabiają. Pozostałe zachowania dotyczyły stwarzania gorszych warunków do rozwoju (np. nieuwzględnianie przy szkoleniach), odmowy udzielenia pomocy czy lekceważenia tych osób ${ }^{28}$.

W kontekście analizowanego tematu warto odnieść się jeszcze do ogólnopolskich badań dotyczących postaw wobec ludzi starszych, które były prowadzone przez Centrum Badania Opinii Społecznej ${ }^{29}$. Wynika z nich bowiem, że co czwarty Polak prezentuje wobec osób w wieku 50+ dystans, obojętność lub niechęć. I chociaż w ciągu ostatnich lat rośnie poziom życzliwości ze strony rodziny, sąsiadów i wspólnot parafialnych, to seniorzy nadal są w swoim środowisku traktowani bardzo różnie. Postawy życzliwości wobec nich cechują głównie środowiska osób dobrze sytuowanych, z wyższym wykształceniem,

\footnotetext{
${ }^{27}$ B. Radzka, Praca w hierarchii wartości pracowników 50+ $i$ wartości zwiazane z praca, [w:] Kompleksowy program aktywizacji osób starszych 50+..., s. 279.

${ }^{28}$ M. Skrzek-Lubasińska, op. cit., s. 332-333.

${ }^{29}$ E. Trafiałek, Warunki integracji i ryzyka dyskryminacji ludzi starszych w rodzinie i środowisku lokalnym, [w:] O sytuacji ludzi starszych, red. J. Hrynkiewicz, Rządowa Rada Ludnościowa, Warszawa 2012, s. 59-60.
} 
natomiast im niższe wykształcenie i gorsze materialne warunki bytu respondentów, tym większa skłonność do krytycznej oceny osób starszych.

\section{ZAKOŃCZENIE}

Szczegółowa analiza zjawiska dyskryminacji ze względu na wiek jest w Polsce mocno utrudniona, ponieważ brakuje cyklicznych i obszernych badań na ten temat prowadzonych przez instytucje państwowe, a nieliczne raporty, opracowywane przez jednostki naukowe lub badawcze, mają zazwyczaj charakter przyczynkowy i obejmują swoim zasięgiem jedynie wybrane regiony kraju. Dokładny monitoring i ocena realizacji polityki antydyskryminacyjnej wymagają systemowego podejścia do procesu zbierania danych o przejawach dyskryminacji na rynku pracy, czego do tej pory nie udało się w Polsce dokonać. Bez analiz empirycznych trudno bowiem rzetelnie i obiektywnie ocenić skalę problemu, jak również skuteczność działań, które można podejmować w celu eliminacji praktyk dyskryminacyjnych.

$\mathrm{Z}$ powodu postępującego procesu starzenia się społeczeństw przeciwdziałanie dyskryminacji ze względu na wiek już wkrótce stanie się istotnym celem polityki gospodarczej (a nie tylko społecznej) w większości krajów na całym świecie. Niekorzystne zmiany w strukturze ludności w wieku produkcyjnym powodują zmniejszanie się zasobów pracy, a w konsekwencji - spadek podaży siły roboczej, który już za kilkanaście lat będzie stanowił bardzo poważny problem ekonomiczno-społeczny. Dlatego też bardzo ważna jest świadomość rangi zjawiska dyskryminacji pracowników w podeszłym wieku na rynku pracy i skutków, jakie mogą wystąpić, gdy aktywizacja zawodowa osób 50+ w przyszłości się nie powiedzie.

Podsumowując wyniki badań empirycznych przedstawionych w artykule, należy zauważyć, że zagadnienie dyskryminacji i marginalizacji osób starszych jest w Polsce bagatelizowane. Zdecydowana większość ankietowanych nie postrzega tego zjawiska jako problemu. Poza wyjątkami, do nierównego traktowania pracowników ze względu na wiek nie przyznają się pracodawcy oraz młodsi pracownicy, chociaż fakty i opinie osób będących adresatem działań dyskryminacyjnych wskazują na inny stan rzeczy. Osoby w wieku 50+ zauważają, że są pomijane przy podwyżkach i premiach, ogranicza się im możliwości rozwoju, ignoruje ich potrzeby i lekceważy.

Sukces polityki antydyskryminacyjnej oraz aktywizacji zawodowej starszych osób wymaga zatem zmian w zachowaniu obydwu zainteresowanych stron. Pracodawcy i młodsi pracownicy powinni się wyzbyć stereotypów i uprzedzeń, ale też osoby w wieku 50+ powinny się zdobyć większą otwartość, chęć współpracy i aktywność. Jest to jednak trudne, wieloaspektowe zadanie wymagające wielu działań systemowych, w których są konieczne realizacja skutecznej polityki państwa $\mathrm{w}$ zakresie systemu emerytalnego i wsparcia starszych pracowników na rynku pracy oraz współpraca instytucji państwowych z organizacjami pracodawców, związkami zawodowymi, a także jednostkami samorządowymi. Zwiększenie zatrudnienia pracowników w podeszłym wieku będzie bowiem możliwe jedynie wówczas, gdy zarówno pracodawcy, jak i osoby 50+ będą świadomi i przekonani co do korzyści, jakie może im dać aktywizacja zawodowa seniorów oraz będą mieli prawne i realne możliwości jej realizacji. 


\section{LITERATURA}

[1] Aronson E., Wilson T.D., Alert R.M., Psychologia spoteczna. Serce i umyst, Zysk i S-ka, Poznań 1997.

[2] Jakość życia i spójność spoteczna 2011 (wstępna analiza wyników badania ankietowego), Notatka informacyjna, GUS, Warszawa 2011.

[3] Jakość życia w Polsce, GUS, Warszawa 2014.

[4] Kompleksowy program aktywizacji osób starszych 50+, red. Cz. Szmidt, Akademia Leona Koźmińskiego, Warszawa 2012.

[5] Krzyżanowska Ł., Homo sovieticus czy doświadczony pracownik? - opinie pracodawców o pracownikach w wieku 50+, „Acta Universitatis Lodziensis. Folia Oeconomica” 2013/291.

[6] Moczydłowska J.M., Kowalewski K., Nowe koncepcje zarządzania ludźmi, Difin, Warszawa 2014.

[7] Osoby powyżej 50 roku życia na rynku pracy w 2013 roku, Ministerstwo Pracy i Polityki Społecznej, Warszawa 2014.

[8] O'Brien L.T., Hummert M.L., Memory performance of late middle-age adults: Contrasting self-stereotyping and stereotype threat accounts of assimilation to age stereotypes, ,Social Cognition" 2006/24.

[9] Posthum R.A., Campion M.A., Age stereotypes in the workplace: common stereotypes, moderators and future research directions, ,Journal of Management” 2009/35.

[10] Piesiak W., Genetyka starzenia się mózgu, „Neurokognitywistyka w Patologii i Zdrowiu. Roczniki Pomorskiej Akademii Medycznej w Szczecinie 2011-2013”, Szczecin 2013.

[11] Richert-Kaźmierska A., Stankiewicz K., Kompetencje pracowników 55+ w opinii pracowników z młodszych grup wiekowych, „E-mentor” 48/1 (2013).

[12] Rizutto T.E., Age and technology innovation in the workplace: Does work context matter?, „Computers in Human Behavior” 2011/27.

[13] Równe traktowanie w zatrudnieniu. Przepisy a rzeczywistość, red. K. Kędziora, K. Śmiszka, M. Zima, Polskie Towarzystwo Prawa Antydyskryminacyjnego, Warszawa 2009.

[14] Skrzek-Lubasińska M., Społeczne uwarunkowania aktywizacji zawodowej osób starszych 50+, [w:] Kompleksowy program aktywizacji osób starszych 50+, red. Cz. Szmidt, Akademia Leona Koźmińskiego, Warszawa 2012.

[15] Sokołowski W., Osoby 45/50+ zmagaja się z dyskryminacją, kariera epr.pl.

[16] Stereotypy i uprzedzenia, red. Z. Chlewiński, I. Kurcz, Instytut Psychologii PAN, Warszawa 1992.

[17] Stop dyskryminacji ze względu na wiek, red. B. Szatur-Jaworska, Agencja Rozwoju Filantropii w Polsce, Warszawa 2005.

[18] Sytuacja osób powyżej 50. i 60. roku życia na rynku pracy Dolnego Śląska, red. J. Sawicki, Centrum Monitoringu Społecznego i Kultury Obywatelskiej, Wrocław 2013.

[19] Trafiałek E., Warunki integracji $i$ ryzyka dyskryminacji ludzi starszych $w$ rodzinie i środowisku lokalnym, [w:] O sytuacji ludzi starszych, red. J. Hrynkiewicz, Rządowa Rada Ludnościowa, Warszawa 2012.

[20] Turner P., Turner S., Van de Walle G., How older people account for their experiences with interactive technology, „Behavior and Information Technology” 2007/26.

[21] Van Dijk J.A.G.M., The Deepening Divide, Inequality in the information Society, Sage, London 2005.

\section{THE STEREOTYPE OF THE WORKER 50+ AS A POTENTIAL SOURCE OF DISCRIMINATORY BEHAVIOUR IN THE IN THE WORK PLACE}

This article aims to systematize knowledge about the stereotypes facing older workers. The article presents an overview of interdisciplinary research on the characteristics and be- 
havior attributed to people at this age group in the work environment. The choice of topic stems from the belief that only thorough knowledge of the stereotypes facing employees aged 50 and over will bring about management processes that are free from discriminatory actions and marginalization of older workers.

The article presents the essence of such concepts as: stereotype, ageism, discrimination and marginalization. It illustrates the characteristics and behaviors that are assigned to people aged 50 and over, and presents evidence of discriminatory treatment, taken from selected reports from national studies on the subject carried out among employees and employers. Lastly, the article presents synthesized findings of studies on the issue of discrimination against older workers.

The collected empirical material allowed us to conclude that the issue of marginalization of older people in the work environment in Poland is rather neglected, and there is little awareness about the content and influence of stereotypes towards mature workers. Employers and younger employees do not admit to the unequal treatment of older employees, yet the facts and opinions of people to whom discriminatory actions are addressed to indicate a different state of affairs. Stereotypical perceptions of workers aged 50+ are recognized as an important source of such behavior.

Keywords: stereotype, age, ageism, marginalisation, discrimination

\section{DOI: 10.7862/rz.2015.mmr.20}

Tekst złożono w redakcji: marzec 2015

Przyjęto do druku: czerwiec 2015 